\title{
Educational Mismatch and Employment Contracts: A Labour Productivity Analysis
}

\author{
Guillaume Vermeylen • Romina Giuliano
}

Published online: 28 August 2014

(C) International Atlantic Economic Society 2014

JEL Classification $\mathrm{D} 21 \cdot \mathrm{I} 00 \cdot \mathrm{J} 21 \cdot \mathrm{J} 50 \cdot \mathrm{C} 33$

The aim of this contribution is threefold. First, we estimate the impact of educational mismatch on a direct measure of firm productivity. Existing literature on the effect of educational mismatch on firm productivity varies widely. Some researchers rely on the human capital theory and investigate the impact of educational mismatch on productivity through its impact on wages (Rumberger, Journal of Human Resources, 1987; Van der Meer, Economics of Education Review, 2006), whereas other researchers rely on the job satisfaction theory and investigate the impact of education on absenteeism, turnover, shirking and other correlates of worker productivity (Tsang, Economics of Education Review, 1987; Hersh, Review of Economics and Statistics, 1991; Tsang et al., Industrial Relations, 1991, Verhaest and Omey, Journal of Economic Psychology, 2009). The main shortcoming of these approaches is that no one investigates the relationship between education and productivity in a direct way.

Second, we provide initial evidence on whether this direct relationship varies according to the type of labour contract. More precisely, we can find two types of labour contracts, i.e. temporary contracts or permanent contracts. Some researchers suggest that favouring permanent labour contracts may increase productivity thanks to the job stability and autonomy that follows (Daubas-Letourneux, TMS et évolution des conditions de travail, 1998; Dubigeon, Mettre en pratique le développement durable - Quels processus pour l'entreprise responsable?, 2005; Bonnechère, Revue Travail et emploi, 2008). On the other hand, temporary contracts may be useful, in terms of flexibility, in order to adjust the size of the firm's labour force according to changes in the business-cycle. In that way, temporary contracts may be used as a buffer to product demand fluctuations (Jahn et al., Economic Journal, 2012).

\footnotetext{
G. Vermeylen $(\bowtie)$

University of Mons, Mons, Belgium

e-mail: Guillaume.Vermeylen@umons.ac.be

R. Giuliano

University of Mons - Free University of Brussels - Walloon Institute for Evaluation, Prospective and Statistics, Mons - Brussels, Belgium

e-mail: Romina.Giuliano@umons.ac.be
} 
Third, this paper implements an intra-country analysis by investigating whether differences in productivity response to educational mismatch according to the type of contract can be found within Belgium, in one of its two main regions, the Wallonia. Some comparisons have already been conducted between countries (Galasi, Budapest Working Papers on the Labour Market, 2008; Harmon et al., Introduction to Education and Earnings in Europe: A Cross Country Analysis of the Returns to Education, 2001), but, to our knowledge, no one has investigated different effects within a country.

We thus estimate microeconometrically how mean years of over- and undereducation within firms affect the productivity of the latter (conditional on mean years of required education) in the whole private sector and according to firm preference in terms of labour contracts. In order to estimate these relationships, we rely on detailed Belgian-linked employer-employee panel data covering the period 1999-2008. The richness of our data offers several advantages. First, the panel provides accurate information on average productivity within firms (i.e. the average value added per worker) and allows us to control for a range of worker and firm characteristics (such as age, occupation, sex, working time, firm size, industry and level of collective wage bargaining). Second, we are able to address important methodological issues such as firm-level time invariant heterogeneity or endogeneity. To do so, we mainly rely on the dynamic system generalized method of moments estimator developed by Blundell and Bond (Journal of Econometrics, 1998, hereafter GMM) and the more structural approach suggested by Levinsohn \& Petrin (Review of Economic Studies, 2003, hereafter LP). The GMM estimator estimates a system of two equations, one in level and one in differences and generates consistent results when estimating a production function with serially correlated productivity shocks and explanatory variables that are correlated to these shocks. On the other hand, the LP estimator also controls for endogeneity but estimates a value-added function by using external instruments, such as material inputs, instead of internal ones.

Our main results first show that increasing the level of over-education has a positive effect on productivity, whereas increasing the level of under-education most often has a negative impact. These results provide support to the human capital theory explanation according to which education develops capabilities that increase worker's productivity. Concerning the labour contracts investigation, the results show that permanent overeducated workers have a positive, significant but also bigger impact on labour productivity than temporary over-educated ones. Turning to the regional specification, it also appears, as for the Belgian specification, that permanent over-educated workers in Wallonia are more productive than temporary over-educated Walloon workers. But, the results also suggest that these permanent over-educated Walloon workers are more productive than their counterparts in other regions of Belgium (Flanders and Brussels). These results suggests that Walloon regional policies, in terms of education, should be beneficial for permanent workers themselves since they benefit from an increase in level of education, but also for the Walloon firms since the Walloon permanent worker's productivity increases as (over-) education increases. 